\title{
Competing in the Shadowy Gray: Protecting Domestic Trademark Holders from Gray Marketeers Under the Lanham Act
}

\author{
Shira R. Yoshor †
}

Frieda the frugal shopper wants to buy a new camera. She sees an advertisement in her morning paper for the latest Nikon model, and, thus inspired, goes to her neighborhood Nikon dealer, Nikons, Etc. Nikons, Etc. is an authorized dealer that has trained personnel to answer any questions that customers may have about the current line of Nikon products. Nikons, Etc. also provides lifetime servicing of its Nikon products. Frieda spends an hour with a very friendly and helpful salesperson. However, Frieda does not purchase a new camera at Nikons, Etc. Instead, she walks down the block to Discount Electronics, a small discount electronics store with no customer service department. Armed with her newly acquired knowledge, she purchases the exact model camera that was demonstrated for her at Nikons, Etc. When her camera does not function properly, she returns to Nikons, Etc. and asks for help. Although the salesperson remembers that Frieda did not actually purchase anything on her last visit, in order to protect Nikons, Etc.'s reputation as a complete servicing agent for all Nikon equipment, he provides Frieda with the assistance that she needs. Nikons, Etc. is damaged in two ways: the free riding for sales advice and the free riding for service.

In the 1980s an enormous market developed for gray market goods, otherwise known as parallel imports. Several years ago, its value was estimated as high as ten billion dollars per year. ${ }^{1}$ Gray market goods, including Johnson's personal care products, Seiko watches, Oil of Olay skin cream, Opium fragrance, Old Spice deodorant, Paco Rabanne pour Homme and Nikon cameras, ${ }^{2}$ are authentic trademarked goods that are imported by someone other than the domestic trademark holder, and are sometimes sold at a

† B.A. 1989, Yeshiva University; J.D. 1992, The University of Chicago.

1 Paula Dwyer and Amy Dunkin, A Red-Letter Day for Gray Marketers, Bus Week 30, (Jun 13, 1988).

2 Joyce Barrett, Discounters Oppose Ban on Gray Goods; Manufactured Goods Made for Sale Overseas, 159 Women's Wear Daily 25 (Apr 5, 1990). 
discount to consumers. Gray market goods are genuine; they are not counterfeit goods exchanged on the black market. Nor are gray market goods stolen products; they are usually purchased abroad by importers and shipped to this country during favorable currency fluctuations. A strong dollar enables the gray marketeer to ship the goods to the United States and often to sell these products at lower costs to consumers than the price charged by the authorized distributor. Additionally, the gray marketeer avoids the advertising and servicing costs borne by the authorized distributor.

Gray markets may also develop from diversion. Diversion occurs when third parties purchase genuine goods, like beauty aids, from licensed product retailers. These beauty aids, made specifically for salons, are then sold to other retailers or discount drug stores at a hefty profit. ${ }^{3}$ A third possibility is that gray markets may develop in products that are produced at lower costs in other countries. These lower costs can often be attributed to lower quality standards. ${ }^{4}$ Sometimes the lower quality standards result from the lack of governmental quality controls. ${ }^{5}$ Other qualitative differences stem from consumer preferences. ${ }^{6}$

In the past, domestic trademark holders have tried several alternatives to curb this unwanted competition from gray market goods, but none have proven entirely successful. Most litigation has involved provisions of the Lanham Act, ${ }^{7}$ the Tariff Act of $1930,{ }^{8}$ state trademark infringement statutes, unfair competition claims, or breach of contract actions. Congress has exacerbated the already unclear status of gray market imports by promulgating ambiguous legislation, which the courts have inconsistently applied to various gray market activities.

Many litigants have relied on the Lanham Act to protect their capital investments in trademarks. Trademark holders have long

3 Elizabeth Chute, Gray Market Persists Amid Lax Customs Laws, 159 Women's Wear Daily, Cosmetic, Toiletry and Fragrance Association Supplement C65 (Feb 23, 1990). See also Sebastian International, Inc. v Consumer Contacts (PTY) Ltd., 847 F2d 1093 (3d Cir 1988).

- Dwight L. Miller, Restricting the Gray Market in Trademarked Goods: Per Se Legality, 76 Trademark Rptr 363, 374-75 (1986), citing Lexecon Inc., The Economics of GrayMarket Imports 1, 44-46 (1985) (unpublished) (on file with U Chi L Rev). This is one of the gray market problems that is addressed later in the Comment.

- Scott D. Gilbert, Eugene A. Ludwig, and Carol A. Fortine, Federal Trademark Law and the Gray Market: The Need for a Cohesive Policy, 18 L \& Policy in Intl Bus 103, 11011 (1986).

- Lever Brothers Co. v United States, 877 F2d 101, 103 (DC Cir 1989).

715 USC §§ 1114, 1124, 1125 (1988).

- 19 USC § 1526 (1988). 
used the Act to combat the importation and distribution of copied or simulated goods in the black market. This traditional application against counterfeit goods is not judicially controversial. ${ }^{\circ}$ Courts are more reticent, however, when asked to apply the Act's protections to prevent the importation and distribution of gray market goods. Application of the Lanham Act requires a finding that consumers are likely to be "confused" by the use of a trademark. ${ }^{10}$ Courts have divided over whether consumers can be "confused" when goods are genuine. Because goods on the gray market are, by definition, not counterfeit or stolen, some courts refuse to recognize claims against importers of gray market goods. Other courts have relied on the differences in quality, physical composition, and customer service packages to find the requisite confusion for Lanham Act protection.

The history, purposes, and development of trademarks and the gray market inform the propriety of the Lanham Act's invocation by domestic trademark holders complaining of gray market infringement. Section I of this Comment focuses on the relationship between the Lanham Act and the prevailing theories of trademark. Section II analyzes the gray market cases, detailing how, when, and in what context they arise. This analysis will demonstrate that the Tariff Act and its attendant Customs Regulations are too limited in scope to effectively control the gray market. Section III details the split among the courts in their application of the Lanham Act to the gray market. Section IV concludes that the Lanham Act protects domestic trademark holders from gray market infringement.

I. Essentials of Trademark Law: The Lanham Act and the Doctrine OF TERRITORIALITY

Recently there have been several cases brought under the Lanham Act by domestic trademark holders seeking to protect their trademarks from gray market importers. The claims put forward by the domestic trademark holders are premised on the purposes of the Lanham Act and the trademark doctrine of territoriality.

- See, for example, Ferrari S.P.A. Esercizio v Roberts, 944 F2d 1235 (6th Cir 1991); Chanel, Inc. $v$ Italian Activewear of Florida, Inc., 931 F2d 1472 (11th Cir 1991); Shell Oil Co. v Commercial Petroleum, Inc., 928 F2d 104 (4th Cir 1991).

10 15 USC \& 1125. 
A. The Purposes of Federal Trademark Legislation: The Legislative History of the Lanham Act

The Lanham Act ${ }^{11}$ was introduced in 1938, and Congress enacted it on July 5, 1946. The Act marked "Congress' attempt at eliminating confusion from the marketplace with regard to the identification of goods and services ...."12 In general, the Lanham Act's prohibitions are directed against the false description or false designation of the origin of goods or services, including false advertising and selling one's goods under the name of a competitor. ${ }^{13}$

Generally, the Lanham Act provides "greater assurance that the good will actually be manufactured to the specifications of the formula"14 by prohibiting the use of confusing words, terms, names, symbols or devices. The statute is directed against:

(a) Any person ... who uses in commerce any word, term, name, symbol, or device . . . which-

(1) is likely to cause confusion, or to cause mistake, or to deceive as to the affiliation, connection, or association of such person with another person, or as to the origin, sponsorship, or approval of his or her goods, services, or commercial activities by another person.... ${ }^{15}$

This language is more specific than the original text, which only generally prohibited the use of false descriptions or representations and false designations of origin in commerce. ${ }^{16}$ Section $43(a)$ enables consumers to rely on particular trademarks for product rec-

${ }^{11} 15$ USC $\$ \S 1051-1127$ (1988).

12 Perini Corporation v Perini Construction, Inc., 915 F2d 121, 124 (4th Cir 1990).

13 Roho, Inc. v Marquis, 902 F2d 356, 359 (5th Cir 1990).

14 William M. Landes and Richard A. Posner, Trademark Law: An Economic Perspective, $30 \mathrm{~J} \mathrm{~L} \mathrm{\&} \mathrm{Econ} \mathrm{265,} 275$ (1987).

${ }^{15}$ Lanham Act $\S 43(a), 15$ USC § 1125.

${ }^{16}$ The original legislation stated:

(a) Civil Action

Any person who shall affix, apply, or annex, or use in connection with any goods or services, or any container or containers for goods, a false designation of origin, or any false description or representation, including words or other symbols tending falsely to describe or represent the same, and shall cause such goods or services to enter into commerce, and any person who shall with knowledge of the falsity of such designation of origin or description or representation cause or procure the same to be transported or used in commerce or deliver the same to any carrier to be transported or used, shall be liable to a civil action by any person doing business in the locality falsely indicated as that of origin or in the region in which said locality is situated, or by any person who believes that he is or is likely to be damaged by the use of any such false description or representation.

15 USC $\S 1125$ (1982). 
ognition, thereby reducing shopping costs and permitting quicker purchasing decisions. ${ }^{17}$

The Senate report on the Lanham Act described its two purposes. First, the Act assures the public that a product bearing a particular trademark is "the product which it asks for and wants to get."18 Trademarks encourage the production of quality products because consumers identify a specific product by its trademark. ${ }^{19}$ Consumers who are dissatisfied with a product will not purchase it again. Consumers who are pleased with a product will identify it by the trademark and purchase it again.

Second, the Lanham Act is designed "to protect 'the synonymous right of a trademark owner to control his product's reputation.' "20 Trademark rights are an integral part of a business of the holder. ${ }^{21}$ The Senate report recognized the importance of trademark protection in thwarting free-rider problems ${ }^{22}$ and preserving goodwill for the domestic trademark holder. ${ }^{23}$ Thus, the report suggests that the enacting senators realized that the value of a trademark is "as real as the value of a manufacturing plant."

B. The Provisions of the Lanham Act

Several provisions of the Lanham Act are potentially available to domestic trademark holders seeking to prevent entry of gray market imports into the United States. Section 42 prohibits

article[s] of imported merchandise . . . which shall copy or simulate a trademark registered in accordance with the provisions of this chapter or shall bear a name or mark calculated to induce the public to believe that the article is manufactured in the United States, or that it is manufactured in any

17 Landes and Posner, $30 \mathrm{~J} \mathrm{~L} \&$ Econ at 269 (cited in note 14).

18 Senate Committee on Patents, S Rep No 1333, 79th Cong, 2d Sess 1 (May 14, 1946), in 1946 USCCAN 1274.

19 J. Thomas McCarthy, 1 Trademarks and Unfair Competition 44 (Lawyers Co-op, 2d ed 1984).

20 Dallas Cowboys Cheerleaders, Inc. v Pussycat Cinema, Ltd., 604 F2d 200, 205 (2d Cir 1979), citing James Burrough, Ltd. $v$ Sign of the Beefeater, Inc., 540 F2d 266, 274 (7th Cir 1976).

${ }^{21}$ See United Drug Co. $v$ Theodore Rectanus Co., 248 US 90, 97 (1918).

${ }^{22} \mathrm{~S}$ Rep No 1333, in 1946 USCCAN at 1274 (cited in note 18) ("Where the owner of a trade-mark has spent energy, time, and money in presenting to the public the product, he is protected in his investment from its misappropriation by pirates and cheats.").

${ }^{23}$ Id ("securing to the owner the good will of his business").

${ }^{24}$ Lexecon, The Economics of Gray-Market Imports at 13 (cited in note 4). 
foreign country or locality other than the country or locality in which it is in fact manufactured $\ldots . .^{26}$

Similarly, § 32 prohibits "use in commerce [of] any reproduction, counterfeit, copy, or colorable imitation of a registered mark in connection with the sale, offering for sale, distribution, or advertising of any goods ... with which such use is likely to cause confusion, or to cause mistake, or to deceive ...."26 The domestic trademark holder is required to show that the gray market importer is using the trademark without the domestic markholder's consent, in connection with the sale of goods, and in a manner likely to cause confusion with the plaintiff's registered trademark.

It is presently unresolved whether $\S 32$ or $\S 42$ are available to domestic trademark holders against gray market imports, since the language of both sections appears to target copies or counterfeit goods-as opposed to the less stringent $\S 43$, which deals with false or misleading goods. Because gray market goods are genuine, these sections of the Lanham Act are a weaker basis for claims against gray market goods than $\S 43$. Moreover, Justice Scalia's dissent in $K$ Mart Corp. $v$ Cartier, Inc. ${ }^{27}$ has arguably ruled out the use of $\S 42$ in the gray market context, although some courts have not considered this dissent dispositive. ${ }^{28} \mathrm{He}$ noted that $\S 42$ of the Lanham Act "prohibits importation of goods of foreign or domestic manufacture bearing not genuine trademarks identical to a United States trademark, but trademarks that 'copy or simulate' a recorded trademark." ${ }^{29}$ At face value, this comment effectively rules out any protection from the gray market based on a claim brought under this section, since gray market goods do not have counterfeit trademarks. However, this statement may not be fatal to domestic tradeholders who seek protection from the gray market under the other sections of the Lanham Act.

Section 43 of the Lanham Act is a better mechanism for domestic trademark holders to prevent gray market importation than either $\S 42$ or $\S 32$. Protection under $\S 43$ (a) requires a showing of a likelihood of confusion. ${ }^{30}$ The plaintiff must "believe [] that he or she is or is likely to be damaged"31 before a court will determine

${ }^{26} 15$ USC $\S 1124$.

${ }^{26} 15$ USC $\$ .1114(1)(\mathrm{a})$.

${ }^{27} 486$ US 281 (1988).

${ }^{28}$ See, for example, Lever Brothers Co. $v$ United States, 877 F2d 101 (DC Cir 1989).

28486 US at $320 \mathrm{n} 1$.

${ }^{30}$ Spring Mills, Inc. v Ultracashmere House, Ltd., 689 F2d 1127, 1129, 1136 (2d Cir 1982).

${ }^{31} 15$ USC § 1125. 
whether consumer confusion has occurred. In Polaroid Corporation v Polarad Electronics Corporation, Judge Friendly set forth a balancing test to determine whether a competing trademark has caused confusion. ${ }^{32}$ The test includes an analysis of:

1) the strength of the mark, 2) the degree of similarity between the two marks, 3) the proximity of the products, 4) the likelihood that the senior user of the mark will bridge the gap, 5) evidence of actual confusion, 6) the junior user's bad faith vel non in adopting the mark, 7) the quality of the junior user's product, and, finally, 8) the sophistication of the relevant consumer group. ${ }^{33}$

If the court concludes, from a consideration of these factors, that the trademark has caused confusion, the Lanham Act protects the trademark holders. ${ }^{34}$ Normally the domestic trademark holder seeks an injunction to prevent the damaging goods from entering the country or to restrict the products from sale. The domestic trademark holder also may be entitled to monetary damages. ${ }^{35}$

However, the courts are divided on whether there can be confusion when the trademark-infringing goods are genuine. Because goods on the gray market are, by definition, not counterfeit or stolen, some courts have refused to recognize trademark claims against unauthorized importers of genuine goods. Other courts have relied on differences in quality, appearance, composition, and service to find consumer confusion when gray market goods are genuine.

\section{Territoriality Versus Universality}

The division in the courts over the applicability of the Lanham Act in gray market litigation stems from a fundamental disagreement over trademark doctrines. The applicability of the Lanham Act in gray market litigation turns on whether courts subscribe to the "universality" or the "territoriality" theory of trademarks.

The traditional "universality" view of trademarks assumes that a trademark knows no territorial bounds and that an owner of

${ }^{32} 287$ F2d 492, 495 (2d Cir 1961).

${ }^{33}$ Centaur Communications, Ltd. $v$ A/S/M Communications, Inc., 830 F2d 1217, 1225 (2d Cir 1987), citing Polaroid, 287 F2d at 495.

${ }^{34}$ The protection afforded to successful plaintiffs under the Lanham Act is outlined in $\S \S 34,35$, and 43(b) of the Lanham Act, 15 USC $\S \S 1116,1117$ and 1125(b) respectively.

${ }^{38}$ Monetary damages are sometimes limited to those who have registered trademarks. See 15 USC \$ $1117(a)$. 
a trademark possesses the trademark's rights to the exclusion of everyone else in the world. ${ }^{36}$ Justice Brennan described the universality approach as one in which "trademarks do not confer on the owner property interests or monopoly power over intrabrand competition. Rather, they merely protect the public from deception by indicating "the origin of the goods they mark." "s7

The corollary that developed in conjunction with the universality doctrine is the theory of "trademark exhaustion." Uns Under the doctrine of trademark exhaustion, trademark owners lose control over their trademarked goods once the goods are released into the stream of commerce. ${ }^{38}$ Consequently, parallel importers and others along the chain of commerce may then display, advertise, and resell the trademarked goods. Some courts, however, have held that exhaustion does not apply when the domestic trademark holder has developed separate and independent goodwill.40

The modern view of trademarks is that of "territoriality." Territoriality is the ability of a company to purchase the rights to a trademark within a specific territory. ${ }^{41}$ The territoriality theory of trademarks dates from Justice Holmes's opinion in the first major gray market case, $A$. Bourjois \& Co., Inc. v Katzel. ${ }^{42}$ Contemporary courts have indicated that the territoriality approach "maintains that the source and scope of trademark protection arise from the law of a particular sovereign state, and thus that it is meaningless to discuss 'genuineness' of a trademark in the abstract." ${ }^{\mathbf{4 3}}$ Another. court described the function of a trademark under the territoriality theory as

not necessarily to specify the origin or manufacture of a good (although it may incidentally do that), but rather to symbolize the domestic goodwill of the domestic markholder so that the consuming public may rely with an expectation of consistency on the domestic reputation earned for the mark by its owner

${ }^{36}$ Osawa \& Co. $v$ B \& $H$ Photo, 589 F Supp 1163, 1171 (S D NY 1984).

${ }^{37} K$ Mart, 486 US at 301, citing $A$. Bourjois \& Co. $v$ Katzel, 275 F2d 539, 543 (2d Cir 1921).

38 McCarthy, 1 Trademarks and Unfair Competition at 261 (cited in note 19). See also Weil Ceramics \& Glass, Inc. v Dash, 878 F2d 659, 677 n 5 (3d Cir 1989) (Becker concurring).

39 McCarthy, 1 Trademarks and Unfair Competition at 261.

to Id. But see NEC Electronics v CAL Circuit Abco, 810 F2d 1506 (9th Cir 1986); Weil Ceramics \& Glass, 878 F2d 659; Olympus Corp. v United States, 792 F2d 315 (2d Cir 1986).

$1 \mathrm{~K}$ Mart, 486 US at 315 (Brennan concurring in part and dissenting in part).

12260 US 689 (1923). See also Coalition to Preserve the Integrity of American Trademarks (COPIAT) v United States, 790 F2d 903, 909-10 (DC Cir 1986).

${ }^{13}$ COPIAT, 790 F2d at 909 (emphasis in original). 
[which permits] the owner of the mark [to] be confident that his goodwill and reputation (the value of the mark) will not be injured through use of the mark by others in domestic commerce. ${ }^{44}$

Because the Paris Convention for the Protection of Industrial Property recognizes that trademark rights are territorial, ${ }^{45}$ territoriality seems to be the accepted modern view of trademarks.. ${ }^{46}$ Modern commercial arrangements, such as licensing and assignment of trademarks for use in a specific territory, similarly indicate that territoriality represents the contemporary understanding of trademarks. ${ }^{47}$ The territorial view captures the essential functions of trademarks, as expressed both by the authors of the Lanham Act and by modern economists. ${ }^{48}$

\section{The Gray Market: The Typical Cases and Their Legal. Postures}

Before 1922, gray market importation into the United States was unrestricted. Even if the trademark rights were purchased by an American corporation and the foreign manufacturer continued to export its products to the United States contrary to its agreement, the American corporation had no legal means to prevent the entry of such imports. ${ }^{48}$ While gray market goods are still imported today, the entry of certain types of gray market goods is prohibited under the Tariff $\mathrm{Act}^{\mathrm{50}}$ and its corresponding regulations.

\section{A. The Three Gray Market Scenarios}

Gray market goods are generally imported in one of three scenarios. The first arises when a domestic company purchases the

14 Osawa, 589 F Supp at 1171-72.

15 Article 6(3) states "[a] mark duly registered in a country of the Union shall be regarded as independent of marks registered in the other countries of the Union, including the country of origin." Paris Convention for the Protection of Industrial Property, 21 UST 1583, 1639 (1967).

(6 This is true because Article VI of the United States Constitution and § 44(b) of the Lanham Act incorporate the Paris Convention for the Protection of Industrial Property into the law of the United States. See US Const, Art VI, cl 2; 15 USC § 1126(b).

${ }^{47}$ See Weil Ceramics \& Glass, 878 F2d at 677 n 5 (Becker concurring) ("The universality theory is no longer viable.").

48 See text at notes $12-24$.

48 Hunyadi Janos Corp. v Stoeger, 285 F 861, 864 (2d Cir 1922); Fred Gretsch Mfg. Co. $v$ Schoening, 238 F 780, 782 (2d Cir 1916); Apollinaris Co. $v$ Scherer, 27 F 18, 20 (S D NY 1886).

so 19 USC § 1526. 
rights to register and use a trademark from a foreign manufacturer, and a third party imports the foreign product. The goods imported are essentially the same as the ones produced by the domestic company who recently invested capital in the trademark. The importer benefits from the consumer recognition of the trademark, which creates a market for his goods.

The Supreme Court prohibited this type of gray market importation in A. Bourjois \& Co., Inc. v Katzel. ${ }^{51}$ This type of importation is also subject to seizure and forfeiture under the Tariff Act. ${ }^{32}$ Clearly, domestic trademark holders need not fear infringement from these types of gray market goods since these gray market goods are legally barred from entry into the United States.

The second type of gray market arises when an American trademark holder authorizes an independent foreign manufacturer to use its trademark in a specific foreign location, but a third party purchases these goods abroad and imports them to the United States. Typically this case will involve licensing agreements or other similar arrangements. ${ }^{53}$ The licensee sells its licensed products to the public in some market and an opportunistic buyer takes advantage of currency fluctuations to purchase the products and sell them in the United States. These gray market goods are barred from entry under the Tariff Act, unless there is written consent from the domestic trademark holder. ${ }^{54}$

The third type of gray market importation occurs when either a foreign corporation establishes an American subsidiary which registers the identical trademark in the United States, ${ }^{85}$ or an American corporation establishes a foreign subsidiary or an unincorporated manufacturing division abroad. ${ }^{58}$ Goods that are manufactured overseas and shipped to the United States by anyone

${ }^{81} 260$ US 689 (1923).

8219 USC \$ $1526(b)$. Also, under 19 USC $\$ 1526(c)$, any person dealing in such merchandise may be enjoined from dealing with such merchandise in the United States or required to export or destroy such merchandise or remove its trademark.

s3 Original Appalachian Artworks, Inc. v Granada Electronics, Inc., 816 F2d 68 (2d Cir 1987), is a perfect example of this gray market scenario. For further discussion, see text at note 89 .

o4 19 USC \$ 1526(a). These goods are no longer exempted from the Tariff Act ban and can be denied entry by Customs officials under the Customs Regulations in 19 CFR § 133.21 (1991).

ss This occurred in Weil Ceramics \& Glass, 878 F2d 659. For further discussion, see text at note 74 .

${ }^{86}$ In Lever Brothers, 877 F2d 101, the domestic trademark holder sued to enjoin the third-party importation of goods produced by Lever UK, a British subsidiary that produced soaps and detergents under the same trademark as Lever USA but with substantial differences to account for the different tastes between consumers in the two markets. 
other than the corporation or its subsidiary fall into this third category of gray market goods. Under the current Customs Regulations, the Tariff Act does not bar importation of these goods. ${ }^{57}$

B. The Most Recent Supreme Court Decision on the Gray Market Issue: $K$ Mart Corp. $v$ Cartier, Inc.

After Congress passed the Tariff Act in 1922, subsequent gray market cases should have been fairly easy to decide. The Tariff Act prohibits importing

into the United States any merchandise of foreign manufacture if such merchandise, or the label, sign, print, package, wrapper, or receptacle, bears a trademark owned by a citizen of, or by a corporation or association created or organized within, the United States, and registered in the Patent and Trademark Office by a person domiciled in the United States ... unless written consent of the owner of such trademark is produced at the time of making entry. ${ }^{58}$

The statute seemed to prohibit entirely the import of "merchandise of foreign manufacture" bearing a trademark owned by a United States corporation. However, a complete ban on gray market imports did not materialize. Because of the haste with which Congress debated and adopted the Tariff Act, ambiguities surrounded it. ${ }^{59}$ Although those supporting the Act stated that its purpose was "to prevent fraud," Congress did not discuss this directive at length.

1. The $K$ Mart holding and the Tariff Act.

In $K$ Mart Corp. $v$ Cartier, Inc., the Supreme Court settled some of the questions surrounding the gray market. ${ }^{61}$ The respondents in $K$ Mart were two members of COPIAT ${ }^{62}$ and the association itself, that challenged the Customs regulations relevant to the

s7 19 CFR \& 133.21(f)(2) (1991).

s8 19 USC $\$ 1526(\mathrm{a})$.

58 The amendment to the Tariff Act left many important questions about its application unanswered before and after its adoption. Senate Debate on Amendment to 19 USC $\S$ 1526, 67th Cong, 2d Sess, in 62 Cong Rec 11605 (Aug 19, 1922).

60 Id at 11603 .

61 486 US 281 (1988).

${ }^{62}$ In 1984, 40 manufacturers and distributors of trademarked goods formed a trade association, the Coalition to Preserve the Integrity of American Trademarks (COPIAT) to formally express their opposition to the gray market. There are now over 60 members. Dwyer and Dunkin, Bus Week at 30 (cited in note 1 ). 
Tariff Act. Those regulations exempted two types of gray market goods from the Tariff Act's ban on importation. First, the Act did not deny entry to gray market goods produced under common ownership or control, meaning either a parent-subsidiary relationship or common individual or aggregate ownership of more than fifty percent. ${ }^{63}$ Second, goods produced abroad that are authorized to use the domestic trademark through licensing agreement or similar arrangement were also exempted from the Tariff Act's restrictions. ${ }^{64}$ Respondents asserted that these regulations were inconsistent with the Tariff Act. ${ }^{65}$ Petitioners, K Mart and 47th Street Photo, intervened as defendants. ${ }^{86}$ The district court upheld the Customs regulations, ${ }^{67}$ but the D.C. Circuit reversed, holding that the Customs regulations were an unreasonable interpretation of the Tariff Act's ban. ${ }^{68}$

Motivated by free-riding and equity concerns, all members of the K Mart Court agreed that the Tariff Act banned gray market goods imported by a third party after a domestic company had purchased rights to use the trademark from a foreign firm. ${ }^{69} \mathrm{Be}$ cause the domestic company has invested in a trademark to profit from its reputation, it would be unfair to force the trademark holder to engage in "sharp intrabrand competition" from importers of the same product who have not incurred the requisite investment expenses. However, the Court stated that imports should not be banned under $\S 1526$ of the Tariff Act when a foreign corporation establishes an American subsidiary which registers the trademark in the United States. ${ }^{70}$ In such a case, the subsidiary is really nothing but a corporate shell for the foreign interest and, therefore, deserves no protection from the United States Tariff Act. Furthermore, the ambiguous nature of $\S 1526$ 's phrase "merchandise of foreign manufacture" would not cover imported goods when

${ }^{63} 19$ CFR $\$ 133.21(\mathrm{c})(1) \&(2)$.

${ }^{64}$ Because the $K$ Mart case struck down this second exception, authorized use is no longer available for gray market importation without consent from the domestic trademark holder. See $K$ Mart, 486 US at 294-95 (holding that 19 CFR $\S 133.21(c)(2)$ was in conflict with the plain language of 19 USC $\$ 1526$ ).

es 486 US at 290.

${ }^{66} \mathrm{~K}$ Mart and 47th Street Photo are frequent purchasers of gray market goods. See Robert J. Staaf, The International Gray Market: The Nexus of Vertical Restraints, Price Discrimination and Foreign Law, 19 U Miami Int-Am L Rev 37, 70 (1987).

${ }^{67}$ Coalition to Preserve the Integrity of American Trademarks ("COPIAT") v United States, 598 F Supp 844, 853 (D DC 1984).

${ }^{88}$ COPIAT, $790 \mathrm{~F} 2 \mathrm{~d}$ at 918.

${ }^{89} \mathrm{~K}$ Mart, 486 US at 292.

70 Id. 
both the foreign and domestic trademarks are owned by the same business entity or by different business entities subject to common control. ${ }^{71}$ Thus, goods produced by the same corporation or by a corporate affiliate under common control would be admitted to the United States even without the written consent of the United States trademark holder. However, gray market goods produced under licensing agreements with foreign manufacturers would be denied entry by Customs.

Under $K$ Mart, the common-control exception still enables gray marketeers to avoid the Tariff Act's ban on their imports. Consequently, some degree of conflict persists as to the appropriate range of trademark legislation and the role it should play in protecting trademark holders. Despite $K$ Mart's holding, this aspect of the gray market problem remains to be solved. This third scenario and its resolution under the Lanham Act are the focus of this Comment.

2. K Mart and the Lanham Act.

Some commentators believe that gray market trademark claims "suffered a set back in the COPIAT [K Mart] opinions."72 However, $K$ Mart only ruled on the propriety of Customs regulations issued pursuant to the Tariff Act. The $K$ Mart Court did not consider the applicability of the Lanham Act.

Justice Scalia noted in his dissent that the first subsection of the Customs Regulations at issue in $K$ Mart was not relevant to the Tariff Act. In this discussion, he mentioned that $\S 42$ of the Lanham Act applies to copies or simulated trademarks; therefore $\S 42$ may be unavailable for domestic trademark holders against gray marketeers. Nevertheless, the fact that $\S 42$ of the Lanham Act may not protect genuine trademarked goods whose trademarks are identical to United States trademarks does not preclude trademark holders' claims under $\S 43$. Section 43 is particularly applicable because it explicitly prohibits trademarks that are confusing to consumers regarding the origin, sponsorship, or approval of goods marked with such trademarks-regardless of the "genuineness" of the trademark. ${ }^{73}$

7 These are the goods exempted under the first two sections of the Customs Regulations, 19 CFR $\S 133.21(c)(1)$ and (2).

72 Jamie S. Gorelick and Julia E. Guttman, Parallel Importation After K Mart v. Cartier (“COPIAT"), $70 \mathrm{~J}$ Patent and Trademark Office Society 696, 700 (1988).

73 See text accompanying notes 30-34. 
The $K$ Mart Court permitted the importation of goods produced by a foreign manufacturer that registers the trademark through a United States subsidiary. Although some argue this point is an indication that the Court did not recognize the territoriality doctrine, ${ }^{74}$ it is more likely that the Court permitted this exception only because foreign companies should not be able to protect themselves under United States tariff law. This construction, based on deference to the agency's interpretation of who "owns" the trademark, ${ }^{75}$ is reasonable in the tariff context, but is inapplicable to the trademark context.

The major consequence of $K$ Mart is that a domestic trademark holder is faced with extreme difficulty in trying to prevent gray market importation when the gray market goods are manufactured abroad by a foreign manufacturer, subsidiary, or an unincorporated division. Because the Court upheld the Customs Regulations permitting the entry of goods that fall within the commoncontrol exception, domestic trademark holders are left without adequate tariff protection against the purveyors of gray market goods. The Lanham Act provides one possible avenue of protection against this infringement. However, as the next Section illustrates, the circuit courts are split on the propriety of using the Lanham Act as a sword against gray marketeers. ${ }^{76}$

\section{The Lanham Act and the Gray Market: Dissension Among the Courts}

Since the decision in $K$ Mart, courts have re-addressed the possible protections available to trademark holders against gray market importers. $K$ Mart clearly upheld the validity of the Customs regulation's common-control exception, and struck down the exception for authorized use. Therefore, trademark holders can seek protection under the Tariff Act if the goods imported were

74 Gorelick and Guttman, $70 \mathrm{~J}$ Patent and Trademark Office Society at 701-02 (cited in note 72).

${ }^{75} \mathrm{~K} \mathrm{Mart}, 486$ US at 292.

78 See Weil Ceramics \& Glass, 878 F2d at 671-72, where the court found that trademark law would be inappropriate to protect the United States subsidiary from gray market imports. Weil Ceramics \& Glass may be restricted to a situation in which a foreign manufacturer establishes a United States subsidiary, since those goods could be imported under the Tariff Act, but not to the other scenarios in which there is common control (i.e., when the United States manufacturer establishes a foreign subsidiary or unincorporated manufacturing division). This was suggested in Lever Brothers, 877 F2d at 111 (discussing the applicability of the Lanham Act as a means of protecting domestic trademark holders against gray market goods and deciding that such a claim would be proper, pending rebriefing of the issue). 
manufactured under a licensing agreement. The gray market problem that remains involves the common-control exception. ${ }^{77}$ Domestic trademark holders' efforts to protect their trademarks from gray market goods through the Lanham Act have met with limited success. The courts disagree over the applicability of the Lanham Act to the gray market context.

Some courts believe that since gray market products are genuine, they cannot cause confusion, and therefore cannot be challenged under $\S 43$ of the Lanham Act. ${ }^{78}$ Others have held that lack of quality control or the physical differences between domestic products and gray market goods bearing the same trademark may cause confusion. ${ }^{79}$ Still other courts have restricted gray market products in order to protect domestic trademark holders from loss of their goodwill or from free-riding. ${ }^{80}$ No clear standard has yet emerged for evaluating trademark claims against gray market importers.

\section{A. Consumer Confusion in the Gray Market Context}

The clearest example of genuine goods that can confuse consumers arises when there are physical differences between the two products. In Lever Brothers Co. $v$ United States, the D.C. Circuit adopted a provisional reading, pending rebriefing, of $\S 42$ of the Lanham Act that would bar "foreign goods bearing a trademark identical to a valid U.S. trademark but physically different, regardless of the trademarks' genuine character abroad or affiliation between the producing firms." Sunlight dishwashing liquid and Shield soap produced in the United Kingdom were significantly different from those versions

77 Legislation clarifying the Tariff Act and redefining the appropriate role of the Customs regulations would be the simplest solution. Many have commented on the lack of congressional and judicial finality in deciding the fate of gray market goods. See Miller, 76 Trademark Rptr at 363 (cited in note 4); Seth E. Lipner, Gray Market Goulash: The Problem of At-the-Border Restrictions on Importation of Genuine Trademarked Goods, 77 Trademark Rptr 77, 91 n 93 (1987).

78 Olympus Corp., 792 F2d at 321; Monte Carlo Shirt, Inc. v Daewoo International (America) Corp., 707 F2d 1054, 1058 (9th Cir 1983); H.L. Hayden Co. of N.Y., Inc. v Siemens Medical Systems, Inc., 879 F2d 1005, 1023 (2d Cir 1989).

70 - El Greco Leather Products Co., Inc. v Shoe World, Inc., 806 F2d 392. 395-96 (2d Cir 1986); Ferrero U.S.A., Inc. v Ozak Trading, Inc., 753 F Supp 1240, 1247 (D NJ 1991); Original Appalachian Artworks, 816 F2d at 73.

so Original Appalachian Artworks, 816 F2d at 73; Premier Dental Products Ca. $v$ Darby Dental Supply Co., Inc., 794 F2d 850, 859 (3d Cir 1986); Osawa, 589 F Supp at 116874.

81877 F2d at 111. No final decision on the outcome of the rebriefing has been published. 
produced in the United States. The versions differed because of "differing consumer preferences, climatic conditions and regulatory standards." ${ }^{\text {" } 2 ~ L e v e r ~ B r o t h e r s ~ s u e d ~ u n d e r ~} \S 42$ to force the Customs Service to seize the British versions of the products.

In Ferrero U.S.A., Inc. $v$ Ozak Trading, Inc., the court considered a domestic trademark holder's $\S 32(1)$ and $\S 43(\mathrm{a})$ challenges to the gray market importation of Tic Tac breath mints produced in the United Kingdom. ${ }^{83}$ Like the court in Lever Brothers, the court also paid careful attention to the fact that the goods were physically different. The Ferrero court distinguished Lever Brothers from Weil Ceramics \& Glass, Inc. $v$ Dash $^{84}$ on the basis that no physical differences in products were apparent in the latter case. ${ }^{88}$ In Ferrero, the United States version of the breath mint differed from the United Kingdom product in size, calorie content, and chemical composition. ${ }^{86}$ The Ferrero court commented that the reasoning and analysis used in the $\S 42$ context of Lever and Weil was equally applicable to the $\S 43$ question. ${ }^{87}$ The material differences in the domestic products and the gray market goods were found to be confusing enough that the court ordered a permanent injunction against the importation and distribution of United Kingdom Tic Tac products in the United States. ${ }^{88}$

The Second Circuit reached a similar conclusion in Original Appalachian Artworks, Inc. $v$ Granada Electronics, Inc.. ${ }^{89}$ There the gray market goods, Cabbage Patch Kids manufactured in Spain, were found to be substantially different from the authorized distributor's and licensee's Cabbage Patch Kids because most of the dolls' "adoption papers" and "birth certificates" were in Spanish, not English. Furthermore, the United States fulfillment houses were not able or willing to process the adoption certificates or mail the birthday cards to the dolls' purchasers, as the authorized licensee did. ${ }^{90}$ The Second Circuit affirmed the district court's order of injunctive relief based on $\S 32$ of the Lanham Act.

82877 F2d at 103.

753 F Supp 1240, aff'd, 935 F2d 1281 (3d Cir 1991).

878 F2d 659 (3d Cir 1989).

so Ferrero, 753 F Supp at 1246. For further discussion see Yamaha Corp. of America $v$ United States, 745 F Supp 730, 732 (D DC 1990).

88 753 F Supp at 1244.

87 Id at $1246 \mathrm{n} 10$ ("The analysis employed in assessing the impact of such action is no less valid and illuminating, merely because a differing statutory provision is in question.").

s8 Id at 1247.

88 816 F2d 68 (2d Cir 1987).

so Id at 73 . 
The cases discussed above indicate the courts' willingness to find consumer confusion when there are substantial differences between the domestic trademark holder's products and the gray market goods. Some domestic mark holders have also been successful in their claims against gray marketeers even when the challenged goods are genuine and lack any observable differences from the domestic goods. ${ }^{91}$ Although the opinions in the cases do not elaborate at great length, it is clear that the decisive factor in each decision was the gray market importer's failure to obtain the trademark holder's consent to the importation. ${ }^{92}$ The courts viewed the lack of sponsorship or consent as tantamount to the sale of non-genuine goods: products cannot be genuine unless the trademark holder approves them for sale. These cases are, however, the exception.

Most courts faced with trademark holders seeking protection under the Lanham Act from gray market imports have decided that genuine gray market goods cannot be confusing. The Second Circuit in Olympus Corp. $v$ United States ${ }^{93}$ stated this position succinctly: "The plain language of [the Lanham Act] does not bar importation if the goods are genuine, only if they 'copy or simulate' a trademark." ${ }^{94}$ Olympus Corporation, the exclusive distributor, trademark holder and wholly owned subsidiary of a Japanese camera manufacturer, challenged the Customs regulations that permitted the gray market imports produced by a foreign parent company. Forty-Seventh Street Photo and K Mart sold this camera equipment at discount prices. Olympus tried to halt the importation of gray market goods, but the Second Circuit upheld the Customs regulation and denied relief under $\S 42$ of the Lanham Act. The court indicated that it would apply the Lanham Act only when counterfeit or spurious trademarks are involved.

21 Premier Dental, 794 F2d at 858; El Greco Leather, 806 F2d at 395.

${ }^{\circ 2}$ See Premier Dental, 794 F2d at 857 ("[T] he legislative history amply demonstrates Congress's intent to bar imports even of 'genuine' goods, where the importation is not authorized by the domestic trademark holder."); El Greco, 806 F2d at 396 (defendant found liable for trademark infringement when it did not "at the minimum seek [] instructions from the [trademark holder] on how to dispose of [the goods]").

o3 792 F2d 315 (2d Cir 1986). Olympus sought declaratory and injunctive relief declaring the Customs Regulations concerning the Tariff Act invalid, or in the alternative, injunctive relief barring the importation of gray market goods under $\S 42$ of the Lanham Act. The court denied relief on both grounds.

" Id at 321. 
B. Damages Asserted Under the Lanham Act: Loss of Goodwill, Lack of Quality Control, and Free-Riding

Recovery under $\S 43$ of the Lanham Act requires a showing of damages. ${ }^{95}$ Domestic trademark holders can be damaged by gray market imports in three ways. First, a domestic trademark holder may assert that gray market goods confuse consumers about sponsorship of the goods and may result in a loss of goodwill. Ordinarily, under the doctrine of exhaustion, once the trademarked goods are released into the stream of commerce, the trademark owner no longer controls them. ${ }^{96}$ However, some courts have held that exhaustion does not apply where the United States trademark holder has developed a separate and independent goodwill.

For example, in Original Appalachian Artworks, the court noted the loss of goodwill from confusion over the source of the Cabbage Patch Kids with foreign-language birth certificates, even though the dolls imported by gray marketeers were produced under a legitimate licensing agreement.97 Similarly, in Premier Dental Products Co. $v$ Darby Dental Supply Co., Inc., ${ }^{98}$ the court noted the loss of goodwill from confusion over the source of the dental products, even though genuine products were imported by the gray market importer.

Second, and a related point, domestic trademark holders may claim that they lack the ability to control the quality of the gray market goods. If the gray market goods are inferior in quality or have some characteristic that distinguishes them from the domestically manufactured products as a result of this lack of quality control, the domestic trademark holder may suffer a loss of goodwill. In El Greco Leather Products, Co., Inc. $v$ Shoe World Inc., ${ }^{99}$ the Second Circuit suggested that the loss of goodwill due to lack of quality control was adequate grounds for an injunction against further importation and a source of damages under the Lanham Act. Even though the shoes at issue were manufactured pursuant to the domestic trademark holder's instructions, the court found a proper cause of action because the shoes lacked certificates of inspection. The court held that the "guarantee function" of trademarks-the ability of the producer to convey information to consumers con-

8s 15 USC \& 1125 (1988).

${ }^{96}$ Original Appalachian Artworks, 816 F2d at 73.

${ }^{87}$ Id.

${ }^{88} 794$ F2d at 859 . The court affirmed the district court's grant of a preliminary injunction under the Tariff Act, 19 USC $\S 1526$.

${ }^{89} 806$ F2d 392 (2d Cir 1986). 
cerning the quality of a product through its trademark $^{100}$-warranted the protection of the Lanham Act. Specifically, the court found that " $[t]$ he mere act of ordering a product to be labeled with a trademark does not deprive its holder of the right to control the product and the trademark."'101

In contrast, other courts have not accepted the loss of the domestic manufacturer's goodwill as a basis for recovery under $\S 43(a),{ }^{102}$ Some courts have dismissed the lack of quality control as an unnecessary inquiry when the goods are genuine, whether or not the companies are under common control. ${ }^{103}$

The third way in which gray market goods may damage trademark holders is through free-riding. Free-riding occurs when a domestic trademark holder, usually the authorized distributor in the gray market context, invests money, time, and effort in developing its trademark. ${ }^{104}$ When third parties import goods manufactured abroad bearing the same trademark as products of a United States trademark owner, they can take advantage of the money the domestic trademark holder has spent on advertising and promotion. They get a "free-ride" because consumers are not aware of the different sources of the product; the consumers only know that they recently saw the trademark advertised on television or through some other media.

However, some courts have been reluctant to recognize injuries from free-riding as redressable in trademark law, at least as against distributors. ${ }^{105}$ For example, in Weil Ceramics \& Glass, the court acknowledged that the domestic trademark holder suffered a "not

${ }^{100}$ Original Appalachian Artworks, 816 F2d at 75, citing R. Callmann, 3A Unfair Competition, Trademarks and Monopolies $\S 12.17$ at 75 (L. Altman, 4th ed 1983).

101 El Greco, 806 F2d at 395-96.

102 NEC Electronics $v$ CAL Circuit Abco, 810 F2d 1506 (9th Cir 1987); Weil Ceramics \& Glass, 878 F2d at 672; Sasson Jeans, Inc. v Sasson Jeans, L.A., Inc., 632 F Supp 1525, 1528-29 (S D NY 1986).

${ }^{103}$ H.L. Hayden, $879 \mathrm{~F} 2 \mathrm{~d}$ at 1023. In Monte Carlo Shirt, Inc. v Daewoo International, the court stated that "absence of Monte Carlo's authorization ... to sell does not alter [the genuine nature of the shirts]." $707 \mathrm{~F} 2 \mathrm{~d} 1054,1058$ (9th $\mathrm{Cir}$ 1983). The lack of quality control was not an adequate ground for protection for an unregistered trademark. The court also doubted the trademark holder's claim that he could not inspect the shirts for quality. The court interpreted the evidence as demonstrating adequate opportunity to inspect and denied relief to the trademark holder. The court believed that an injunction barring the importation of the genuine goods was not warranted since there was no actionable commonlaw trademark infringement. Id at 1057-58.

104 Miller, 76 Trademark Rptr at 373-74 (cited in note 4). The Senate report listed the concern with free riding in its description of the evils that the Lanham Act was designed to combat. S Rep No 1333, in 1946 USCCAN at 1274 (cited in note 18).

${ }^{105}$ See Weil Ceramics \& Glass, 878 F2d at 672 n 18. 
inconsequential or insignificant" injury from the gray market importer's free-riding on Weil's advertising and promotion costs, ${ }^{106}$ but refused to use trademark law to provide a remedy. To justify its decision, the court offered only the fact that the domestic trademark holder was not entirely uncompensated because of its parent corporation's profits from the sale abroad to the third party. ${ }^{\mathbf{1 0}}$

However, several courts have acknowledged the unfair results that occur when free-riding is allowed. The court in Osawa \& Co. $v$ $B \& H$ Photo described in great detail the plaintiff's advertising expenditures and public relations efforts, noting that they were incurred "largely for the benefit of its competitors, the grey market sellers, who free ride on plaintiff"s publicity."108 Accordingly, the court granted the plaintiff a preliminary injunction on trademark claims brought under Sections 32,42 , and 43 of the Lanham Act and under the Tariff Act. ${ }^{109}$ Similarly, the court in Original Appalachian Artworks ${ }^{110}$ pointed out that the domestic licensee of the trademark invested millions of dollars to advertise the Cabbage Patch Kids. The gray market importer had unfairly capitalized on the popularity obtained through the licensee's advertising campaign.

In summary, the courts have expressed divergent opinions over whether gray market goods can cause-consumer confusion and whether domestic trademark holders are damaged by the sale of such goods. This lack of uniformity evidenced by these divergent opinions demonstrates the need for a clear delineation of the appropriate application of the Lanham Act in the gray market context. The next Section explains how the Lanham Act may be used against gray marketeers.

${ }^{108}$ Id at 672.

${ }^{20 z}$ Id. Because Weil was the wholly owned subsidiary of the Spanish porcelain manufacturer, Lladro, its parent company profited from the sale of its products abroad. Even though a portion of these sales were to gray market importers whose imports competed with Weil's sales, the Third Circuit believed that Weil profited indirectly from this sale of Lladro products abroad. Since the trademark holder was a wholly owned subsidiary of the foreign manufacturer, the corporate entity "has an obvious self-help mechanism: it can cease the sale to [importer] and thereby eliminate effectively its United States competition ...." Id at 668 .

${ }^{108} 589 \mathrm{~F}$ Supp at 1168.

109 Id at 1179.

110816 F2d at 71. 
IV. The Lanham Act: Protection for Domestic Trademark Holders from Gray Market Goods

The legislative history of the Lanham Act demonstrates that Congress intended to protect the trademark investments of domestic trademark holders from gray market importers. The Lanham Act was designed to shield consumers from confusion and to safeguard the goodwill created by the domestic trademark holder. The Supreme Court did not decide this issue in $K$ Mart, which involved the Tariff Act, not the Lanham Act. This Section argues that courts should recognize trademark claims asserted against gray marketeers by domestic trademark holders under the Lanham Act.

\section{A. The Purposes of the Lanham Act}

While some commentators have encouraged United States trademark owners to pursue claims against gray marketeers under the Lanham Act to protect their trademark interests from infringement, ${ }^{111}$ the courts are divided on the same question. The provisions of the Lanham Act appear helpful to domestic trademark holders. The plain language of $\S 43$ addresses:

any false designation of origin, false or misleading description of fact ... which-(1) is likely to cause confusion, or to cause mistake, or to deceive as to the affiliation, connection or association ... . or as to the origin, sponsorship, or approval of his or her goods.... 112 $^{12}$

Because the language is rather broad, the Lanham Act's legislative history is helpful in discerning the Act's proper role in gray market cases.

Congress clearly intended the Lanham Act to be used "to prevent diversion of trade through misrepresentation ....".113 This is what I refer to below as protection of the domestic trademark holder's investment. ${ }^{114}$ The Senate committee that reported on the bill which was to become the Lanham Act also stated that for "the protection of the public against deception, a sound public policy requires that trade-marks should receive nationally the greatest

"11 See, for example, Siegrun D. Kane, The Gray Market and Trademark Infringement: Are Genuine Goods Created Equal?, $70 \mathrm{~J}$ Patent and Trademark Office Society 677 (1988); William H. Allen, The Supreme Court's Gray Market Decision, $70 \mathrm{~J}$ Patent and Trademark Office Society 688, 693 (1988).

11215 USC \& 1125(a).

${ }^{133} \mathrm{~S}$ Rep No 1333, in 1946 USCCAŃ at 1277 (cited in note 18).

${ }^{114}$ See Section IV.A.2. 
protection that can be given them."115 In support of this proposition, the Senate committee cited Justice Holmes's opinion in Kat$z e l$, the first major gray market case. ${ }^{116}$

1. Protection against confusion.

The trademark protects the public by allowing purchasers to distinguish among competing goods and choose the product they desire. ${ }^{117}$ As illustrated by the cases in which the domestic trademark holder's products are physically different from the gray market products bearing the same trademark, gray market goods frustrate this purpose. This was best demonstrated in Lever Brothers and Ferrero. ${ }^{118}$ In both of these cases there were significant and confusing physical differences between the domestically-trademarked good and the good branded abroad with the same trademark.

There is often the possibility that goods imported by those other than the authorized dealer are inferior to those carried by the authorized distributor. For example, the goods may have been damaged during the trip overseas. ${ }^{119}$ Additionally, goods with a limited shelf life may experience a reduction in quality because of the time that it takes to import them to the United States. ${ }^{120}$

Consumers are often completely unaware of the possible problems with gray market goods. The purchaser may not realize that the product does not comply with government standards, ${ }^{121}$ or that the imported goods are different from those produced domestically. ${ }^{122}$ In such cases, the trademark loses its utility because it no

$125 \mathrm{~S}$ Rep No 1333, in 1946 USCCAN 1277 (cited in note 18).

116 Justice Holmes briefly described a trademark as "stak[ing] the reputation of the plaintiff upon the character of the goods." Bourjois, 260 US at 692.

${ }^{117} \mathrm{~S}$ Rep No 1333, in 1946 USCCAN at 1275.

118 See text at notes 81-88.

${ }_{112}$ See Adolph Coors Co. v A. Genderson \& Sons, Inc., 486 F Supp 131 (D Colo 1980) (quality of beer rendered inferior due to non-refrigerated storage); Comment, Applying Grecian Formula to International Trade: $\mathrm{K}$ Mart Corp. v. Cartier, Inc. and the Legality of Gray Market Imports, 75 Va L Rev 1397, 1416 (1989).

${ }^{120}$ In the Matter of Certain Alkaline Batteries, 225 USPQ (BNA) 823 (USITC 1984), nonacq 225 USPQ (BNA) 862, appeal dismissed sub nom Duracell, Inc. $v$ United States International Trade Commission, 778 F2d 1578 (Fed Cir 1985).

${ }^{121}$ See Scott D. Gilbert, Eugene A. Ludwig, and Carol A. Fortune, Federal Trademark Law and the Gray Market: The Need for a Cohesive Policy, $18 \mathrm{~L}$ \& Policy in Intl Bus 103, 110-11 (1986) ("Many Igray market] products do not comply with U.S. ingredient labelling requirements. Others may contain ingredients prohibited by federal law because they may cause severe allergic reactions or may be carcinogenic.") (footnotes omitted).

${ }^{122}$ Several states, including New York, California, and Connecticut have passed laws to combat this specific problem. The legislation requires labeling on gray market goods to 
longer indicates a level of quality or some other recognizable characteristic.

Courts have sometimes recognized the problem of consumer confusion that can result from gray market products, particularly when the domestically-produced goods are physically different from their gray market counterparts. ${ }^{123}$ This reading is the most faithful to the purposes of the Lanham Act. Indeed, $\S 43$ of the Lanham Act is designed to protect consumers from "any goods" that are "likely to cause confusion, or to cause mistake, or to deceive as to the affiliation, connection, or association of such person with another person, or as to the origin; sponsorship, or approval of his or her goods, services, or commercial activities . . . ."124 This Comment argues that $\S 43$ can and should be used to combat the confusion engendered by gray market goods that possess different characteristics from domestic goods branded with the same trademark.

Unfortunately, courts that have found that genuine goods do not confuse consumers cannot account for consumers' inability to determine whether differences exist between the domestic product and those imported on the gray market. ${ }^{125}$ Regardless of whether the trademark was legally placed on the package, the courts have overlooked the possibility that identical trademarks might represent different information for different geographical areas. ${ }^{126}$

heighten consumer awareness of the possibility that the products they are purchasing may differ in some respects from the domestic counterparts with which they are familiar. NY Gen Bus Law § 218-00(3) (McKinney 1988); Cal Civ Code § 1797.81 (West 1988); Conn Gen Stat $\$ 42-210$ (West 1986).

${ }_{123}$ See Section III.A.

12415 USC $\$ 1125$ (a).

128 Yamaha Corporation of America v United States, 703 F Supp 1398, 1401-02 (C D Cal 1988) (electronic equipment manufactured by trademark owners' foreign parent is genuine and cannot cause confusion); Diamond Supply Company $v$ Prudential Paper Products Co., Inc., 589 F Supp 470, 475-76 (S D NY 1984) ("identical or qualitatively equivalent" stationary cannot cause public confusion); Monte Carlo Shirt, 707 F2d at 1058 (genuine shirts, manufactured for trademark holder under contract, cannot cause confusion); Parfums Stern, Inc. v United States Customs Service, 575 F Supp 416, 417 (S D Fla 1983) (sale on gray market of uncontroverted, equally good, legitimate fragrance products does not harm public); American Honda Motor Co., Inc. v Carolina Autosports Leasing and Sales, Inc, 645 F Supp 863, 867 (W D NC 1986) (genuine automobiles will not cause confusion); Sasson Jeans, 632 F Supp at 1528-29 (genuine jeans, whose manufacture and trademark affixation was authorized by trademark holders, cannot cause consumer confusion). ${ }^{128}$ See the discussion of the territorial nature of trademarks in Section IV.B. 
2. Protection of investment by domestic trademark holder.

Gray market imports also undermine the second purpose of the Lanham Act, the protection from "misappropriation by pirates and cheats."127 Such misappropriation ordinarily appears as loss of goodwill or free-riding.

a) Loss of goodwill. Courts that have recognized damages under the Lanham Act stemming from lost goodwill can trace redressability of lost goodwill to the Senate report on the Lanham Act. ${ }^{128}$ The Senate report specifically states that one of the goals of the Lanham Act was to "secure trade-mark owners in the goodwill which they have built up . . .."129 Some courts have seized upon the Senate's clear interest in protecting goodwill and recognized claims for lost goodwill. ${ }^{130}$ As in Lever Brothers, ${ }^{131}$ domesticallyproduced goods may be physically different from those manufactured abroad. Once the purchaser discovers these discrepancies, she may be disappointed or confused. For example, in the hypothetical which introduced this Comment, Frieda may be disappointed by the unreliability of the gray market Nikon camera she purchased. The authorized distributor, who is readily identified with the product through marketing efforts, suffers a loss of goodwill that may translate into decreased sales.

Loss of goodwill is also a concern with consumers who are unaware of the origin of the goods and may mistakenly expect warranty and repair services from the authorized distributor of the product. ${ }^{132}$ Recall that Frieda took her camera back to the authorized dealer for servicing. If the authorized distributor honors the gray market consumer's request for service, it loses money because the dealer has not profited from the sale of the good but incurs the expense of servicing the product under the customary warranty provisions. On the other hand, if the domestic trademark holder refuses to provide these services, he may lose the consumer's brand loyalty and forfeit possible future sales. ${ }^{133}$ Either way, the domestic trademark holder's bottom line profitability is impaired.

${ }^{127}$ S Rep No 1333, in 1946 USCCAN at 1274 (cited in note 18).

128 Id at 1276.

128 Id.

${ }^{130}$ See text accompanying notes 95-100.

131877 F2d 101 (DC Cir 1989). See also Ferrero, 753 F Supp 1240.

${ }^{132}$ See, for example, Rich Warren, Walkman and friends: A Guide to Pocket Stereo, Chi Trib, Du Page Sports Final Edition 67 (Nov 17, 1989).

${ }^{133}$ This predicament arose in NEC Electronics, 810 F2d at 1508 (some purchasers thought their goods were covered by trademark holder's servicing and warranties), and 
b) Losses from free-riding. The Lanham Act is a proper means of combatting free-riding by gray marketeers. One of the purposes of the Lanham Act is to protect the investments of domestic companies in trademark development and maintenance. ${ }^{134}$ " $[F]$ ree-riding is more likely where domestic marketing costs are a larger share of the total costs of producing and marketing a product, and where shipping costs are a smaller share."135 Thus, freeriding is more problematic with goods that can be easily shipped, but are relatively expensive for the authorized distributor to advertise. ${ }^{136}$ Gray market goods are very often small products like perfume, watches, cameras, batteries and cosmetics. ${ }^{137}$ Shipping these products is fairly easy because of their size, yet advertising costs for these goods are fairly high. ${ }^{138}$

Part of the impact of free-riding is that trademark owners lose potential sales to gray marketeers. This stems from a perhaps mistaken consumer perception that they can purchase the same products at a lower cost. ${ }^{139}$ Because the quality difference in these products is often undetectable at the time of the sale, consumers will purchase the less expensive good, unaware of its potential flaws. Because of this free-riding, many major gray market importers can offer gray market products at a lower cost; they need only incur the relatively small costs of transportation, while the authorized distributor bears the much more substantial costs of advertising and promotions. ${ }^{140}$

Gray market importers do not only free-ride on the domestic trademark holder's advertising expenditures. They also free-ride on personnel employed by the authorized dealer. Distributors often train retailers and may even provide them with free customer samples. $^{141}$ As a result, the trained retailers can provide consumers with more guidance in choosing between goods. Recall that Frieda spent an hour with the Nikons, Etc. salesperson. She learned enough through his demonstrations of different equipment to con-

Osawa, 589 F Supp at 1168 (trademark holder must provide free servicing or suffer damage to his mark).

${ }^{134}$ See Park 'N Fly, Inc. v Dollar Park and Fly, Inc., 469 US 189, 198 (1985).

${ }^{135}$ Lexecon, The Economics of Gray-Market Imports at 34 (cited in note 4).

${ }^{136}$ Id at 7,35 .

137 See text accompanying note 2 .

${ }^{138}$ Lexecon, The Economics of Gray-Market Imports at 35.

130 William H. Allen, Some Revisions of Gray Market Decalogue: A Response to Messrs. Lewin and Steele, 10 Hastings Comm/Ent L J 1075, 1079 (1988).

140 Lexecon, The Economics of Gray-Market Imports at 7, 35.

141 For an example of a distributor who invested resources in training retailers, see Osawa, 589 F Supp at 1166. 
fidently make a purchasing decision. If customers know that they can get detailed, time-consuming, and helpful demonstrations from authorized retailers, and then purchase similar products from gray market importers, free-riding will erode distributors' willingness to train personnel. ${ }^{142}$

Sometimes, however, gray market importers or the stores which purchase from them offer their own refunds, return policies, or warranties independent of the authorized distributor. ${ }^{143}$ Retail stores like Montgomery Ward and $\mathrm{K}$ Mart switched to gray market importers for some items because of those importers' better service and value. ${ }^{144}$ These department stores are unlikely to be deceptive in selling defective goods because they depend on repeat sales as much as an authorized distributor. ${ }^{145}$ However, these stores are distinguishable from smaller gray market importers who can afford to be deceptive because they can easily get in and out of the market. ${ }^{146}$ Opponents of the gray market are primarily concerned with these small importers.

The COPIAT organization opposes gray market imports for the additional reason that the continued influx of such products may eventually lead to domestic unemployment. Free-riding may cripple American authorized distributors, affecting production of the domestic manufacturer. ${ }^{147}$ Organized labor also has strong concerns about the "erosion of the branded products produced by Americans, leaving currently productive workers unemployed."148

The legislative history of the Lanham Act indicates that protection of American industry was one of its major objectives: "to secure to the business community the advantages of reputation and good will by preventing their diversion from those who have created them to those who have not." 149 In summary, the Lanham Act should be read to protect trademark owners from the harmful effects of free-riding on the goodwill that they have created.

${ }^{142}$ Lexecon, The Economics of Gray-Market Imports at 42 (cited in note 4).

${ }^{143}$ Staaf, $19 \mathrm{U}$ Miami Int-Am L Rev at 69 (cited in note 66).

144 Id at 70.

145 Id.

146 Id.

${ }^{147}$ Note, The Gray Market and the Customs Regulation-Is the Controversy Really Over After K Mart Corp. v. Cartier, Inc.?, 65 Chi Kent L Rev 221, 227-28 (1989).

${ }^{1 * 8}$ Bureau of National Affairs, Bill To Curb Gray Market Imports Debated at Hearing by Senate Judiciary Committee, 7 Intl Trade Rptr 551 (Apr 18, 1990).

${ }^{349} \mathrm{~S}$ Rep No 1333, in 1946 USCCAN at 1275 (cited in note 18). 


\section{B. The Territoriality Doctrine in the Gray Market Context}

The ability of a trademark to serve a territorial function is acknowledged as the dominant theory of trademark law today. ${ }^{150}$ The adoption of the territorial approach is significant. Under the territoriality view, any trademark that is not that of the trademark holder for the territory in which the product is sold will confuse consumers. This is true no matter how genuine that trademark is for another territory.

The courts that recognize the possibility of consumer confusion with gray market goods that are "genuine" also recognize that trademarks serve a territorial function. Territoriality recognizes that a trademark has "a separate legal existence in each nation"1.51 that can be assigned according to the dictates of the Paris Convention. ${ }^{162}$ Courts that believe that trademarks serve only to indicate the source of manufacture ignore the potential confusion that can occur even if the trademark was affixed legally in one territory. These courts overlook the fact that one trademark can be used in different territories by different distributors, and consequently can represent different qualities for consumers from different areas.

The trademark rights held by an owner in one country are distinct from the rights of an identical trademark owned in another country under international law. ${ }^{153}$ Domestic trademark holders should be able to protect themselves from free-riding and loss of goodwill, even if the gray market goods are produced by a foreign manufacturing subsidiary or division subject to the same control as the domestic trademark holder. The cases illustrate the possibility that even those products manufactured by companies under "common control" may be different enough to cause substantial confusion among consumers. This confusion should be recognized by courts as an injury redressable under the Lanham Act since it is confusing as to "the origin, sponsorship, or approval of his or her goods, services, or commercial activities by another person."154

\section{Conclusion}

Injunctions against the importation of gray market goods should be available to domestic trademark holders. The need for

\footnotetext{
${ }^{150}$ See text at notes $41-48$.

151 David Bender and Daniel Gogek, Gray Market Goods: Substantive Law, The Law of Gray and Counterfeit Goods 67 (Practicing Law Institute 1987).

${ }_{152}$ McCarthy, 2 Trademarks and Unfair Competition at 536 (cited in note 19).

153 Id.

15415 USC \& 1125(a).
} 
such protection is best illustrated in cases where the gray market goods have substantially different characteristics from products manufactured domestically carrying the same trademarks. Some gray market products do not conform to government standards. Others do not come with the warranties or services offered by the authorized distributor. Still others may be inferior in quality.

These discrepancies indicate that gray market goods can potentially harm a trademark owner's reputation if such goods are associated with his or her products. Therefore, domestic trademark holders should be allowed to bring suits against importers of gray market products to protect their trademark investments. It is logical that the statute created specifically for protection against trademark infringement should protect these trademark owners from possible infringement of gray market goods.

The language and the history of the Lanham Act support its applicability to protect domestic trademark holders' rights from violation by gray market importers. Until federal legislation is passed to resolve this issue, suits under the Lanham Act will enable trademark holders to protect their investments and unassuming consumers from the possible evils of the gray market. 